\title{
Serum Uric acid levels in Preeclamptic and Normotensive pregnant females
}

\author{
Author \\ Dr Anisha (MD Biochemstry) \\ Garg medical agencies, Beri Wali Gali, Sirsa, Haryana, India \\ Email: kansal.anisha@gmail.com
}

\begin{abstract}
To study serum Human uric acid levels in pre-eclamptic and normotensive pregnant females.

Study Design: Case control study.

Methodology: The study was divided into two groups (Group I and Group II).

Group I included the cases i.e. pre-eclamptic females of gestation of $>20$ wks

Group II included the controls i.e. normotensive pregnant females of same gestation. The serum uric acid levels were evaluated in the two groups.

Results: The mean Serum uric acid in the study group were $6.008 \pm 0.942 \mathrm{mg} \%$ against $4.175 \pm 0.627 \mathrm{mg} \%$ in control group, $p$ value was $<0.001$ which was foud to be highly significant.

Keywords: Preeclampsia, Uric Acid.
\end{abstract}

\section{Introduction}

Pre-eclampsia is a disease OF multisystem characterized by the development of hypertension after 20 weeks of gestation in a previously normotensive woman, with the presence of proteinuria. $^{[1]}$

In the early pregnancy uric acid levels decrease because of the increase in excretion of uric acid because of estrogen and due to rise in renal blood flow. Uric acid levels then increase during the third trimester, However, in patients of pre-eclampsia, increased serum uric acid levels are found during the first trimester in association with a relative decrease in urinary urate excretion. The increase in levels of uric acid correlates with the severity of the maternal and fetal morbidity including small-forgestational-age (SGA) infants and fetal death. ${ }^{[2]}$
Rise in uric acid concentration can lead to reduced production of Nitric Oxide and lead to altered endothelial contribution to vascular tone in preeclampsia. Uric acid is a potent mediator of inflammation. In vascular smooth muscle cells uric acid also lead to rise in the concentration of the chemokine monocyte chemo attractant protein-1 (MCP-1) mRNA and protein.

Uric acid also stimulates human monocytes to produce the pro-inflammatory cytokines IL-1 $1 \beta$, IL-6 and TNF- $\alpha$, which also rise in preeclampsia. In preeclamptic women the increased concentration of circulating TNF- $\alpha$ was positively correlated to circulating uric acid concentrations, also elevations in circulating uric acid follow an acute ischemiareperfusion event ${ }^{[3]}$

The objective of this study was to compare serum uric acid in preeclampsia and normal pregnancy. 


\section{Material and Methods}

The study was conducted in Biochemistry Department in collaboration with Obstetrics and Gynaecology department at Rajindra Hospital, Patiala.

70 pregnant women were selected for the study and were divided into 2 groups: 1. Group-I (cases) consisting of 50 patients having Pre-eclampsia of >20 weeks gestation 2. Group-II (control) consisting of 20 normotensive pregnant females of $>20$ weeks gestation.

Inclusion Criteria: 1. Blood pressure $\geq 140 / 90$ mmHg. 2. Excretion of $\geq 1+$ dipstick of urinary protein/24hrs.

Exclusion Criteria: 1. All cases of essential hypertension or chronic hypertension due to any other cause. 2. Any associated renal, hepatic, neurological disorders not due to pregnancy induced hypertension. 3. Associated molar pregnancy.

Blood sample, under all aseptic conditions, was collected by venipuncture and allowed to clot. The serum was then separated by centrifugation of the sample at room temperature. Serum Uric Acid Levels were estimated by Caraway's Method 4.

Normal levels of Serum Uric Acid = 2.4-6.0 mg/dL (females)

All findings were recorded, tabulated and statistically analyzed.

\section{Results}

\begin{tabular}{|c|c|c|c|c|}
\hline $\begin{array}{l}\text { Clinical } \\
\text { Data }\end{array}$ & $\begin{array}{l}\text { Study } \\
\text { group }\end{array}$ & $\begin{array}{l}\text { Control } \\
\text { group }\end{array}$ & p value & Significance \\
\hline Age (yrs) & $\begin{array}{c}24.8 \pm \\
4.508\end{array}$ & $\begin{array}{l}25.1 \pm \\
3.864 \\
\end{array}$ & 0.795 & $\begin{array}{c}\text { Not } \\
\text { Significant }\end{array}$ \\
\hline $\begin{array}{l}\text { Gestational } \\
\text { age (wks) }\end{array}$ & $\begin{array}{c}31.66 \pm \\
3.589\end{array}$ & $\begin{array}{c}31 \pm \\
4.328 \\
\end{array}$ & 0.515 & $\begin{array}{c}\text { Not } \\
\text { Significant }\end{array}$ \\
\hline $\begin{array}{l}\text { SBP } \\
(\mathbf{m m H g})\end{array}$ & $\begin{array}{c}155.8 \pm \\
16.681 \\
\end{array}$ & $\begin{array}{c}117 \pm \\
7.24 \\
\end{array}$ & $<0.001$ & $\begin{array}{c}\text { Highly } \\
\text { Significant }\end{array}$ \\
\hline $\begin{array}{l}\text { DBP } \\
(\mathrm{mmHg})\end{array}$ & $\begin{array}{l}103.3 \pm \\
11.985 \\
\end{array}$ & $\begin{array}{l}74.8 \pm \\
5.818 \\
\end{array}$ & $<0.001$ & $\begin{array}{c}\text { Highly } \\
\text { Significant }\end{array}$ \\
\hline $\begin{array}{l}\text { Serum Uric } \\
\text { acid }\end{array}$ & $\begin{array}{c}6.008 \pm \\
0.942 \\
\mathrm{mg} \%\end{array}$ & $\begin{array}{c}.175 \pm \\
0.627 \\
\mathrm{mg} \%\end{array}$ & $<0.001$ & $\begin{array}{c}\text { Highly } \\
\text { Significant }\end{array}$ \\
\hline
\end{tabular}

\section{Discussion}

According to study by Masoura $\mathrm{S}$ et al in year 2015 oxidative stress, angiogenic imbalance, placental ischemia and an inflammation have been supposed to play role in the pathogenesis of the disease. Also rise in uric acid levels were found to be due to disfunction in kidneys in preeclampsia. ${ }^{[5]}$

Paramanic T et al did a study in 2014 and found high blood pressure [SBP $149.42 \pm 12.35$ vs $109.00 \pm 7.93 \mathrm{~mm} \mathrm{Hg}$; DBP $96.85 \pm 8.32$ vs $72.5 \pm 7.10$ $\mathrm{mm} \mathrm{Hg}]$, and serum uric acid level $[6.27 \pm 1.37 \mathrm{vs}$ $4.27 \pm 0.61 \mathrm{mg} / \mathrm{dl}]$ in pre-eclamptic patients compared to their normotensive pregnant females. ${ }^{[6]}$ As per Vázquez-Rodríguez $\mathrm{JG}^{1}$, Rico-Trejo EI. study in 2011,2 Uric acid is a end product of the degradation of nucleotides, which rise in patients with preeclampsia-eclampsia, increasing in its formation due to damage and death of proliferating trophoblasts and decreased urinary excretion due a lower glomerular filtration rate and increased absorption in the proximal tubule ${ }^{[7]}$

Uric acid inhibits endothelial function, lead to systemic and glomerular hypertension and passes freely into the fetal circulation. Uric acid also inhibit VEGF-induced endothelial proliferation and thus may block fetal angiogenesis. Uric acid can also inhibit trophoblast invasion in vitro. ${ }^{(2)}$

\section{Conclusion}

A higher level of uric acid is found in patients of preeclampsia as compare to normotensive pregnant females

\section{References}

1. Moussa, H.N.; Arian, S.E.; Sibai, B.M. Management of hypertensive disorders in pregnancy. Womens Health 2014, 10, 385404. [CrossRef] [PubMed]

2. Richard J.J., Kenbey M, Kang D Uric acid: A Clinically Useful Marker to Distinguish Preeclampsia from Gestational Hypertension. Hypertension. 2011 Oct; 58 (4): 548-549.

3. Bainbidge AS,Robert MJ, Uric Acid as a Pathogenic Factor in Preeclampsia. Placenta. 2008 Mar; 29(Suppl A): S67-S72.

4. Varley H . Non protein nitrogen.,urea,urate, creatine and creatinine. In:Practical clinical Biochemistry, $5^{\text {th }}$ edn Heinemann 1980;45187. 
5. Masoura S1, Makedou K, Theodoridis T, Kourtis A, Zepiridis L, Athanasiadis A The involvement of uric acid in the pathogenesis of preeclampsia. Curr Hypertens Rev. 2015;11(2):110-5.

6. Pramanik T, Khatiwada B, Pradhan P. Serum uric acid level in normal pregnant and preeclamptic ladies: a comparative study Send to Nepal Med Coll J. 2014 Sep;16 (1):30-2.

7. Vázquez-Rodríguez JG1, Rico-Trejo EI. Role of uric acid in preeclampsia-eclampsia] Ginecol Obstet Mex. 2011 May;79(5):292-7. 